\title{
Peran Film Animasi Nussa dan Rara Dalam Meningkatkan Pemahaman Tentang Ajaran Islam Pada Pelajar SD
}

\author{
Airani Demillah \\ e-mail: airani@gmail.com
}

\begin{abstract}
Education is very necessary, in children especially with. islamic education, technology development expected to bring influence positive for children who by presenting entertainment or impressions, educate as animated show entitled islamic, on youtube including nussa. rara and This study aims to to see how the role of animated film nussa rara and channel on youtube in increasing understanding about islamic teachings on a stone, students of elementary schools with the riau with qualitative research. The determination of sample used is purpose of sampling. Based on the research done respondents got teaching or knowledge on the movie. Through his messages, every episode of Nussa and Rara always teaches something about daily habits or activities based on Islamic teachings, this also adds to their knowledge of daily habits or activities carried out according to Islamic teachings.
\end{abstract}

\section{Keywords: Film, Animation, Youtube, Nussa and Rara}

\begin{abstract}
Abstrak
Pendidikan sangat diperlukan pada anak-anak, terutama dengan pendidikan Islam. perkembangan teknologi, diharapkan dapat membawa pengaruh yang positif bagi anak-anak yaitu dengan menghadirkan hiburan atau tayangan yang mendidik, seperti tayangan animasi bertema Islami di youtube, diantaranya Nussa dan Rara. Penelitian ini bertujuan untuk mengetahui bagaimana Peran film animasi Nussa dan Rara di channel youtube dalam meningkatkan pemahaman tetang ajaran Islam pada pelajar SD Bagan Batu, Riau dengan metode penelitian kualitatif. Penentuan sample yang digunakan adalah purpose sampling. Berdasarkan hasil penelitian responden mendapat pengajaran atau ilmu yang bermanfaat dari film tersebut. Melalui pesan-pesannya, setiap episode Nussa dan Rara selalu mengajarkan sesuatu hal mengenai kebiasaan atau kegiatan sehari-hari berdasarkan ajaran Islam, hal ini juga yang menambah pengetahuan mereka tentang kebiasaan atau kegiatan sehari-hari yang dilakukan sesuai ajaran Islam.
\end{abstract}

Kata Kunci: Film, Animasi, Youtube, Nussa dan Rara 


\section{Latar Belakang Masalah}

Pendidikan sangat diperlukan pada anak-anak, terutama dengan pendidikan Islam. Pendidikan Islam adalah usaha orang dewasa muslim yang bertakwa secara sadar mengarahkan dan membimbing pertumbuhan serta perkembangan fitrah (kemampuan sadar) anak didik melalui ajaran Islam ke arah titik maksimal pertumbuhan dan kekurangannya.

Seiring dengan perkembangan teknologi, diharapkan dapat membawa pengaruh yang positif bagi anak-anak. Untuk meningkatkan pemahaman tentang Islam pada anak, haruslah diberikan sesuai dengan zamannya, yaitu dengan menghadirkan hiburan atau tayangan yang mendidik, seperti sebuah film bernuansa Islami. Tidak hanya menyenangkan bagi anak, tetapi anak-anak juga mendapat pelajaran dari film tersebut.

Menurut Rossi dan Breidle dalam Sanjaya (2008: 204) mengemukakan bahwa media pembelajaran adalah seluruh alat dan bahan yang dapat dipakai untuk tujuan pendidikan, seperti radio, televisi, buku, koran, majalah, dan sebagainya. Menurut Rossi, alat-alat semacam radio dan televisi kalau digunakan dan diprogramkan untuk pendidikan, maka merupakan media pembelajaran.

Dalam situasi pembelajaran terdapat pesan-pesan yang harus dikomunikasikan. Pesan tersebut biasanya merupakan isi dari tema atau topik pembelajaran. Pentingnya pemanfaatan film dalam pendidikan sebagian didasari oleh pertimbangan bahwa film memiliki kemampuan untuk menarik perhatian orang dan sebagian lagi didasari oleh alasan bahwa film memiliki kemampuan 
mengantar pesan secara unik.

Produk teknologi yang paling

Film atau gambar hidup

merupakan gambar-gambar dalam

frame di mana frame demi frame

diproyeksikan melalui lensa

proyektor secara mekanis sehingga

pada layar terlihat gambar itu hidup.

Sama halnya dengan film, video

dapat menggambarkan suatu obyek

yang bergerak bersama-sama dengan

suara alamiah atau suara yang

sesuai. Kemampuan film dan video

melukiskan gambar hidup dan suara

sehingga memberi daya tarik

tersendiri. Kedua jenis media ini

pada umumnya digunakan untuk

tujuan-tujuan hiburan, dokumentasi,

dan pendidikan. Mereka dapat

menyajikan informasi, memaparkan

proses, menjelaskan konsep-konsep

yang rumit, mengajarkan

keterampilan, menyingkat atau

memperpanjang waktu, dan

mempengaruhi sikap. banyak memberi pengaruh terhadap

anak saat ini adalah produk

teknologi informasi dan komunikasi,

seperti televisi (TV), internet, games

elektronik, handphone (smartphone).

Dengan kecanggihan teknologi,

menonton video atau menonton

sebuah film saat ini sudah bisa

dilakukan dengan menggunakan

handphone. Namun, tidak dapat

dipungkiri jika tayangan atau film

yang tersedia di media, tidak

sepenuhnya baik untuk ditonton

anak-anak.

Salah satu media yang

menyediakan berbagai macam video

yang dapat ditonton dari kalangan

dewasa hingga anak-anak yaitu akun

youtube. Youtube merupakan

sebuah media yang menfasilitasi

penggunanya untuk berbagi video

atau menonton video. Youtube mulai

berdiri pada bulan Februari 2005 di 
San Bruno, California, Amerika

Serikat yang diprakasai oleh tiga orang founder youtube, yaitu Chad Hurley, Steven Chen, dan Jawed Karim.

Tingginya jumlah penonton Indonesia di situs video online terbesar di dunia itu yang menjadi salah satu alasan Google memboyong youtube ke tanah air. Adam Smith, Director of product management youtube Asia Pasific saat meresmikan youtube Indonesia di FairGrounds, Jakarta, Kamis (14/6). Smith mengungkapkan, sekitar $70 \%$ penonton youtube berasal dari luar AS, dan Indonesia menjadi salah satu pengguna youtube terbesar di Asia. "Penonton youtube dari Indonesia menghabiskan puluhan juta jam per hari. Ini merupakan angka yang luar biasa." Ujarnya. Liliweri (2015: 308).
Youtube versi Indonesia ini menonjolkan sejumlah konten lokal. Mulai dari logo, bahasa, dan juga tayangan video dalam situs tersebut. Pada logo situs yang beralamat www.youtube.com itu ditampilkan background gambar wayang, serta siluet hitam dari tugu Monas, yang mencirikan Indonesia, para pengguna di Indonesia dapat membuka youtube akan langsung di direct ke konten berisi video lokal. "Dengan peluncuran domain lokal untuk Indonesia, kami akan memberikan konten yang lebih dekat dengan pengguna disini. Seperti video yang paling populer dan beberapa produk yang menjadi rekan bisnis produk kami di Indonesia," ujar Rudy Ramawy, Country Head Google Indonesia. Liliweri (2015: 306-308).

Tayangan yang tersedia di youtube salah satunya yaitu film 
animasi. Film animasi adalah film yang merupakan hasil dari pengolahan gambar tangan sehingga menjadi gambar yang bergerak. Pada awal penemuannya, film animasi dibuat dari berlembar-lembar kertas gambar yang kemudian di-"putar" sehingga muncul efek gambar bergerak. Dengan bantuan computer dan grafika komputer, pembuatan film animasi menjadi sangat mudah dan cepat. Bahkan akhir-akhir ini lebih banyak bermunculan film animasi 3 dimensi daripada film animasi 2 dimensi.

Harrison dan Hummell (2010: 21-22) menyatakan bahwa film animasi mampu memperkaya pengalaman dan kompetensi siswa pada beragam materi ajar. Film dapat dikatakan sebagai media belajar karena film merupakan salah satu bentuk perwujudan yang bersifat teknis dari metode cerita yang memuat kisah-kisah menarik, ringan, menghibur dan mendidik. Film mampu menarik dan memikat perhatian penontonnya tanpa memakan waktu lama. Pesan pendidikan akan lebih mudah disampaikan pada anak-anak dengan cara-cara yang menyenangkan.

$$
\text { Hegarty (2004: }
$$

menjelaskan bahwa dengan perkembangan teknologi dewasa ini, film animasi mampu menyediakan tampilan-tampilan visual yang lebih kuat dari berbagai fenomena dan informasi-informasi abstrak yang sangat berperan untuk meningkatkan kualitas proses dan hasil belajar. Tayangan animasi bertema Islami yang tersedia di youtube salah satunya berjudul Nussa dan Rara. Tayangan ini diharapkan dapat memberi edukasi dan pemahaman tentang Islam terutama pada anak. Tayangan animasi ini memiliki dua 
karakter utama kakak beradik, Nussa

dan Rara. Animasi ini berkisah

tentang Nussa dan Rara (adik Nussa)

gadis kecil berusia 5 tahun yang

gemar bermain mobil balap. Dikutip

dari tulisan di akun resmi Nussa

Official, lahirnya animasi ini

dilatarbelakangi oleh kecemasan

keluarga akan tontonan anak yang

jarang sekali menawarkan kebaikan,

terutama yang sarat akan nilai-nilai

Islami.

Animasi Nussa dan Rara tidak

hanya lucu dan menggemaskan, tetapi juga sarat akan nilai moral dan

pelajaran yang seharusnya

didapatkan anak-anak terutama nilai-

nilai Islami. Penggambaran karakter

Nussa dan Rara yang lucu dan menggemaskan, dikemas dengan cara berpakaian yang baik dan sopan serta mencerminkan nilai ajaran Islam, sudah menjadi contoh untuk siapapun yang menontonnya terutama bagi anak-anak.

Tidak hanya itu, pengajaran dan pengetahuan akan ajaran Islam pada film Nussa dan Rara dapat diperoleh di setiap episodenya, ditambah dengan pesan-pesan berbentuk nasehat dan mengandung unsur ajaran Islam yang di tampilkan di setiap bagian akhir film. Episode dalam film animasi Nussa dan Rara menayangkan kebiasaan atau aktivitas sehari-hari yang dilakukan berdasarkan ajaran Islam dengan cara penyampaian dari karakter yang mudah dipahami oleh penonton.

Dapat dikatakan, penyampaian mengenai ajaran Islam pada film Nussa dan Rara dilakukan dengan metode ceramah, dimana Nussa mengajarkan atau memberi nasehat kepada Rara mengenai kebiasaan atau aktivitas yang dilakukan berdasarkan ajaran Islam dalam kehidupan sehari-hari, dan Rara 
sebagai adik Nussa senantiasa mendengarkan dengan antusias tentang apa yang dikatakan sang kakak. Sebaliknya, Rara juga mengingatkan Nussa, apabila sang kakak melupakan sesuatu dalam melakukan kebiasaan atau aktivitas sehari-hari. Misalnya membaca basmallah sebelum bepergian Sehingga dalam hal ini, baik Nussa maupun Rara juga mengajarkan untuk saling mengingatkan satu sama lain tentang hal baik yang di ajarkan oleh Islam.

Karakter ibu dalam film animasi Nussa dan Rara disebut sebagai umma. Dalam film animasi Nussa dan Rara, karakter umma juga turut membimbing dan memberikan pengajaran yang baik pada Nussa dan Rara berdasarkan ajaran Islam, apabila mereka menanyakan sesuatu hal yang belum mereka ketahui. Anak-anak sekarang, yang sering sekali terpapar gadget (perangkat elektronik kecil yang memiliki fungsi khusus) terkadang menonton hal-hal yang tidak baik dan tidak layak untuk usia mereka. Hadirnya Nussa dan Rara adalah sebagai contoh untuk si kecil dalam melakukan banyak hal baik.

\section{Metode Penelitian}

Dalam penelitian ini, menggunakan metode penelitian deskriptif kualitatif. Penelitian deskriptif yaitu mengumpulkan data berdasarkan faktor-faktor yang menjadi pendukung terhadap objek penelitian, kemudian menganalisa faktor-faktor tersebut untuk dicari peranannya (Arikunto, 2010: 151). Bogdan dan Taylor (1975: 5) mendefenisikan metodologi kualitatif sebagai prosedur penelitian yang menghasilkan data deskriptif berupa kata-kata tertulis atau lisan 
dari orang-orang dan perilaku yang

dapat diamati. Menurut mereka, pendekatan ini diarahkan pada latar dan individu tersebut secara holistik (utuh) jadi, dalam hal ini tidak boleh mengisolasikan individu atau organisasi ke dalam variabel atau hipotesis, tetapi perlu memandangnya sebagai bagian dari sesuatu keutuhan.

\section{Hasil Penelitian dan Pembahasan}

Dari hasil penelitian, Ternyata film animasi Nussa dan Rara ini memiliki kelebihan, terutama dalam menambah pengetahuan melalui media online dengan cara yang menyenangkan dan sesuai dengan dunia mereka di kalangan pelajar SD Pembangunan Bagan Batu, Riau. Pelajar mengaku menyukai film animasi Nussa dan Rara yang di publish di aplikasi youtube. Meskipun rata-rata dari mereka belum memiliki smartphone sendiri dan jarang menggunakannya, namun mereka sudah mengetahui teknologi komunikasi tersebut, dan mengetahui salah satu aplikasi media sosial bernama youtube. Hal ini juga yang menjadi alasan kenapa mereka lebih sering menonton televisi daripada bermain smartphone.

Pelajar SD Pembangunan Bagan Batu, mengaku selain menggunakan aplikasi Wattpad, mereka juga akrab dengan aplikasi media sosial lainnya seperti, Game online dan Facebook. Namun, mereka mengaku lebih sering mengakses aplikasi game online. Pelajar SD Pembangunan Bagan Batu yang diteliti, umumnya menikmati film Nussa dan Rara. Bahkan rata-rata dari mereka sangat antusias dan terbawa suasana saat menontonnya, hal ini terlihat dari 
berbagai ekspresi yang mereka tunjukkan, ada yang tertawa saat film tersebut menampilkan adegan lucu, dan ada yang ikut bernyanyi saat salah satu episode menampilkan sebuah lagu yang berkaitan dengan judul.

Pelajar SD Pembangunan Bagan Batu yang diteliti, rata-rata dari mereka mendapatkan pengajaran tentang Islam melalui film tersebut, terutama bagi mereka yang belum mengetahui sama sekali mengenai kegiatan atau kebiasaan sehari-hari yang dilakukan sesuai ajaran Islam. Hal ini dikarenakan, film Nussa dan Rara selalu menayangkan adegan mengenai aktivitas sehari-hari yang dilakukan berdasarkan ajaran Islam. Penyajian film yang dilakukan dengan cara menyenangkan dan sesuai dengan dunia mereka, membuat para pelajar SD Pembangunan Bagan Batu mudah memahami dan mengerti tentang apa yang disampaikan film tersebut. Tidak hanya mengaku jika film tersebut mengandung bayak hal yang bermanfaat dan pengajaran yang baik, pelajar SD Pembangunan Bagan Batu, beberapa diantaranya merasa jika film tersebut mengingatkan dan mengajarkan mereka mendekatkan diri pada Allah SWT.

\section{Penutup}

Berdasarkan hasil penelitian dan pembahasan, maka dapat di tarik kesimpulan bahwa rata-rata siswa/siswi di SD Pembangunan Bagan Batu, pada umumnya mengetahui dan menyukai film animasi Nussa dan Rara di channel youtube. Walaupun mereka tidak terlalu sering menonton film Nussa dan Rara, namun, mereka mengatakan mendapat pengajaran 
atau ilmu yang bermanfaat dari film

tersebut. Ini dibuktikan dengan

alasan yang mereka berikan karena

menyukai film itu.

Rata-rata dari mereka yang belum mengetahui mengenai pesanpesan bermanfaat yang mengandung ajaran Islam di akhir durasi film tersebut, menjadi tahu mengenai ajaran Islam yang selama ini belum mereka ketahui. Tidak hanya melalui pesanpesannya, setiap episode Nussa dan Rara selalu mengajarkan sesuatu hal mengenai kebiasaan atau kegiatan sehari-hari berdasarkan ajaran Islam, hal ini juga yang menambah pengetahuan mereka dari yang belum tahu, menjadi tahu tentang kebiasaan atau kegiatan sehari-hari yang dilakukan sesuai ajaran Islam.

\section{Daftar Pustaka}

Arikunto, Suharsimi. 2010. Prosedur Penelitian : Suatu Pendekatan Praktik, Edisi Revisi VI, Jakarta: Rineka Cipta.

Bogdan, Robert dan Taylor, 1975 Pengantar Metode Penelitian Kualitatif, Surabaya: Usaha Nasional.

Harrison, Henry L, Hummel, Laura J. (2010). Incorporating Animation Concepts and Principles in STEM Education. The Technology Teacher. USA Page 20-25.

Hegarty, Mary. (2004). Commentary Dynamic Visualizations and Learning: Getting to The Difficult Questions. Learning and Instruction. 14, 343-351.

Heriyanto, Prabowo, Aan. 2013. Jurnal Ilmu Perpustakaan Volume 2, Nomor 2.

Liliweri, Alo. 2015. Komunikasi Antarpersonal. Jakarta: Kencana.

Sanjaya, Wina. 2008. Perencanaan dan desain sistem pembelajaran. Jakarta: Kencana Prenada Media Group. 